\title{
ASSESSMENT OF PRODUCTIVITY AND RESOURCE USE EFFICIENCY OF RICE UNDER DIFFERENT ESTABLISHMENT METHODS AND NUTRIENT MANAGEMENT IN CHITWAN CONDITION, NEPAL
}

\author{
Chandika Lama ${ }^{1}$ and Santosh Marahatta ${ }^{2}$
}

\begin{abstract}
A field experiment was conducted in sub humid climate of inner terai of Nepal to determine the productivity and economics of rice under direct seeded and transplanted methods under different nutrient management in strip plot design with three replications in 2013, rainy season. The treatment consisted of three tillage methods, conventional tillage direct seeded rice, unpuddled transplanted rice and Puddled transplanted rice and five nutrient management practices Recommended Nitrogen $(N)$, Phosphorous $(P)$ and Potassium(K), 100:30:30 Kg NPK ha ${ }^{-1}$; Leaf color chart based N + Recommended PK; Farmers' Practice, 48.30:34.50:0.00 Kg NPK ha ${ }^{-1}$ ON + Recommended PK and 150\% of Recommended NPK. The result revealed that grain and straw yield were not significant due to crop establishment methods. LCC based N application yield was comparable with $150 \%$ of Rec. NPK and Rec. NPK. Saving N on LCC based N management with $41.56 \mathrm{Kg} \mathrm{ha-1}$ and $9.44 \mathrm{Kg} \mathrm{N}$ ha ${ }^{-1}$ over $150 \%$ of recommended NPK recommended NPK respectively. Adoption of CT-DSR reduced the total cost of cultivation by $30.13 \%$ and B:C ratio by $45.95 \%$ over P-TPR. The lower cost, higher benefit and the same production, revealed that LCC based N management under CT-DSR was the best management practices over the conventional P-TPR.
\end{abstract}

Keywords: Conventional Tillage Direct Seeded Rice (CT-DSR), unpuddled transplanted rice (UP-TPR), Puddled transplanted rice (P-TPR), recommended (Rec.), Leaf color chart (LCC),

\section{INTRODUCTION}

Rice (Oryza sativa L.) is the most important food, consumed by half of the world's population. It is staple food of $90 \%$ of Asian population and gaining staple value in Latin America and Africa (IRRI, 2015a). In Asia food security is equivalent to rice security. Globally it is grown in 158 million hectares, producing more than 700 million tons annually and nearly 640 million tons of rice is grown in Asia which is $90 \%$ of the global production (IRRI, 2015b).

Rice in Nepal is economically important as it has the highest growing area $(1.42$ million ha, $46 \%$ of the total cultivated land) among all the agricultural commodities (MoAD, 2013/14). Share of rice is $20 \%$ to the agriculture gross domestic product (GDP) and contributes nearly $50 \%$ of the calorie requirement of Nepalese people (NARC, 2007).

Although rice is major crop of Nepal, the productivity is very low $\left(3.17 \mathrm{t} \mathrm{ha}^{-1}\right)(\mathrm{MoAD}$, 2013/14) in Nepalese condition compared to other major rice growing countries and areas (China, $6.72 \mathrm{t} \mathrm{ha} \cdot 1$ and India $3.61 \mathrm{t} \mathrm{ha}$ ) (IRRI, 2014). It is estimated about 503-544 million tones is to be required by 2030 which requires $1 \%$ increase per year by keeping 2010 as the base year (FAO, 2014) globally. The possibility of expanding the area under rice in future is very limited. Therefore, the required extra production has to come through increase in productivity. The major challenge of low yield is to achieve this gain with less water, labor, and chemicals, ensuring long-term sustainability

$1 \quad$ Planning officerDADO,Bardiya, Email: chandika.lama41@gmail.com

2 Assistant Professor, Department of Agronomy, Agriculture and Forestry University (AFU), smarahatta@afu.edu.np; 9845449092 
(Kumar and Ladha,2011). Agronomic management and technological innovations are needed to address these issues at present.

Rice is commonly grown by transplanting seedlings into puddled soil. Major Asian countries like Malaysia, Philippines, Thailand and Mekong Delta are thus transferring traditional transplanting of rice (TPR) to direct seeded rice (DSR) which has marked shift of establishment method (Pandey \& Velasco, 2002).

Nutrient management is another issue regarding the increased productivity. Among the entire macro nutrient Nitrogen is assimilated in higher amount by plants being almost yield-limiting nutrient in rice and rice based cropping system (Ladha \& Reddy, 2003). After green revolution the use of nutrient has been increasing with the highest use of Nitrogen among all which accounts $72 \%$ of relative consumption of N, P and K (Ladha, Pathak, Krupnik, Six \& Kessel, 2005).

Nitrogen dynamics in puddled rice have been extensively studied (De Datta \& Buresh, 1989). Mineral $\mathrm{N}$ dynamics in dry land preparation may differ from those in puddling and continuous flooding. In puddled anaerobic conditions, ammonium nitrogen $\left(\mathrm{NH}_{4}{ }^{-} \mathrm{N}\right)$ is available (Reddy ,Patrick \& Broadbent, 1984), while under aerobic conditions $\mathrm{N}$ is available in the form of nitrate nitrogen $\left(\mathrm{NO}_{3}\right.$ N) (George et al.,1992). Increased accumulation of $\mathrm{NO}_{3}-\mathrm{N}$ in the soil profile increases the potential for $\mathrm{N}$ leaching to shallow water tables (Al-Kaisi \& Licht, 2004). Further, the frequent aerobicanaerobic phases promote $N$ losses by denitrification (Vlek \& Byrnes, 1986). The poor utilization efficiency is further favored by insufficient splitting of $N$ with use of $N$ in excess amount (Singh, Sharma \& Prasad, 2001). The nutrient requirement of the dry land preparation is drastically differ from the conventional puddling and flooding due to differential nutrient cycle. Thus, availability of mineral $\mathrm{N}\left(\mathrm{NO}_{3}-\right.$ and $\left.\mathrm{NH}_{4}-\mathrm{N}\right)$ in the soil and the rate of uptake by rice may differ across tillage practices. If proper splitting can be followed considering the growth stages the loss can be minimized significantly. Thus synchronizing supply of $\mathrm{N}$ with crop demand depending on its growth habit and duration will ultimately optimize $\mathrm{N}$ use efficiencies and reduce $\mathrm{N}$ losses. In this regard, improved technology regarding the higher $\mathrm{N}$ use efficiencies should be directed towards the identifying nitrogen need through LCC (Balasubramanian, Ladha, Gupta, Naresh, Mehala, Singh \& Singh, 2003)and maximizing uptake and reducing the transformation losses (De Datta, 1986) being a potential solution.

\section{OBJECTIVE}

- $\quad$ To assess the effects of different nutrient management on growth and yield of rice established on conventional tilled dry direct seeded and puddled and unpuddled transplanted rice,

- $\quad$ to evaluate the yield and economic performance of conventional tilled dry direct seeded and puddled and unpuddled transplanted rice, and

- $\quad$ to evaluate the nutrient use efficiencies of conventional till dry direct seeded and puddled and unpuddled transplanted rice.

\section{THEORETICAL FRAMEWORK}

\section{Cultural practices of rice}

Puddling is common traditional method of establishment of rice. It is most commonly operated in wetland by transplanting in the prepared land after irrigating the field. Unpuddled transplanting is quiet laborious and energy consuming method of rice establishment resulting into high cost of 
production compared with transplanted rice. Production is also low compared with transplanted rice (De Datta, 1981). Its' adoption seems to be non-profitable in most of the cases.

Direct seeded rice (DSR) refers to the process of establishing a rice crop from seeds sown in no till or conventional till field rather than transplanting young seedlings from the nursery to main field. There are three principal methods of Direct seeded rice (DSR) :dry seeding, wet seeding and water seeding. Direct seeding of rice is gaining popularity in Asian countries (Kumar \& Ladha, 2011). The major drivers of DSR from transplanted rice are water and labor scarcity.

\section{Nitrogen management}

There was increase in plant height with increase in the $\mathrm{N}$ applied (Manzoor, Awn, Zahid \& Faiz., 2006). According to Patil, Singh, Singh, Mishra, Das, and Henao (2001) all growth parameters, yield, yield associated attributes and $\mathrm{N}$ accumulation are significant to $\mathrm{N}$ levels at all three years of experiments in DSR, whereas thousand grains weight were non-significant to $\mathrm{N}$ levels. According to him the grain yield was significantly responsive to applied $\mathrm{N}$ up to $120 \mathrm{Kg} \mathrm{N}$ ha ${ }^{-1}$ in direct seeded rice.

Timing is critical factor in $\mathrm{N}$ application. The growth and development in rice plant are periodic thus proper timing not only reduces the cost involved for nutrient management but also enhanced yield. Early application of $\mathrm{N}$ contributes to the root development. Early application of $\mathrm{N}$ at early stage yields higher than applied at mid-season. $\mathrm{N}$ applied at flag leaf and heading stages result in high fertilizer $N$ uptake and do not bring substantial increase in grain yield but protein content is increased (Marahatta,2008). Transplanting shock are common which last up to about 7days, so it is very much likely that most $\mathrm{N}$ applied may not be used by plant or lost (Marahatta,2008)

The grain yield and straw yield was significant to the time of application as reported by Salam et al. (1998). The same scientist reported that the two split applications (half at basal and half at tillering) and three split applications ( $1 / 2$ at basal, $1 / 4$ at tillering and $1 / 4$ at panicle initiation) were significant to produce grain yield of $3.7 \mathrm{t}$ ha-1 for both practice and $5.6 \mathrm{t}$ ha-1 and $5.7 \mathrm{t}$ ha-1 respectively than other practice of splitting.

Nitrogen cycle in a soil plant dynamic is influenced by soil, plant and climatic factor. This cycle involves the biochemical changes of organic and inorganic changes of Nitrogen. The Nitrogen in the soil is majorly depleted by absorption by plant, adsorption by soil colloids, losses as gases through volatilization (Sloan \& Anderson, 1955)and denitrification, leaching (Fageria et al.,2003) and microbial immobilization (Shimpi \& Savant, 1975) into the deeper layer of soil .

\section{METHODOLOGY}

The experiment was operated in the research block of agronomy farm of Agriculture and Forestry University Rampur, Chitwan from May to October, 2014. This station comes under subtropical and humid climate. The soil was sandy loam with slight acidity and had medium organic matter, phosphorous and nitrogen and low potassium.

The experiment was laid out in strip-plot design with two factors and three replications having 21 treatment combinationsfor Radha-4 improved rice variety. Two factors taken in experimentation were establishment practices in horizontal strip and nutrient management practices in vertical. Within establishment practices there were three methods: (i) Conventional dry direct seeded Rice (CT-DSR), (ii) puddled transplanted rice(P-TPR) and (iii) unpuddled transplanted rice (UP-TPR). The nutrient management practices involved seven practices: (i) recommended NPK, (ii) LCC based N + recommended PK, (iii) farmers' fertility management practice, (iv) nitrogen omission ( $\mathrm{ON}+$ recommended PK), (v) $150 \%$ of recommended NPK, (vi) phosphorus omission (OP + recommended $\mathrm{NK}$ ) and (potassium omission (vii) $\mathrm{OK}+$ recommended NP). 


\section{Conventional Dry Direct Seeded Rice}

Direct seeding of rice involved establishment of rice through seed in the field. This experiment was done through dry bed seeding method. Unpuddled transplanting is commonly practiced mechanically. The nursery raising and transplanting was done on the same day on UP-TPR and P-TPR. Puddled transplanted rice was done by transplanting the rice seedling which was 21 day old in the puddled field.

In treatments which consisted of recommended dose of nitrogen, $100 \mathrm{Kg} \mathrm{N}$ ha'1, nitrogen was applied at transplanting (33.33\% i.e. $33.33 \mathrm{Kg} \mathrm{ha} \cdot)$, at tillering $(33.33 \%)$ and at panicle initiation $(33.33 \%)$. In LCC based nitrogen application, $25 \%$ of recommended dose (25 Kg N ha $\cdot)$ was applied as basal dose. The remaining nitrogen (from urea) was top dressed through LCC reading at critical value at $20 \mathrm{Kg} \mathrm{N}$ ha ${ }^{\prime}$ in each dose. Fertilizer in farmers' fertility management practice was $48.30: 34.50: 0.00 \mathrm{Kg} \mathrm{NPK}$ ha ${ }^{-1}$. The nitrogen was applied at transplanting $(34.59 \mathrm{Kg} \mathrm{ha} \cdot 1)$ and at tillering $(13.71 \mathrm{Kg} \mathrm{ha} \cdot 1) . \ln 150 \%$ of recommended dose, $150: 45: 45 \mathrm{Kg} \mathrm{NPK}$ ha-1 nitrogen was applied at transplanting $(33.33 \%$ i.e. 50 $\left.\mathrm{Kg} \mathrm{ha}{ }^{-1}\right)$, at tillering (33.33\% i.e. $50 \mathrm{Kg} \mathrm{ha-1)}$ and at panicle initiation (33.33\% i.e. $50 \mathrm{Kg}$ ha-1).

\section{RESULT}

\section{Effect of $L C C$ readings on $N$ fertilization in rice}

The data showed that there was negligible saving of nitrogen under puddled TPR condition and required more nitrogen under unpuddled TPR and CT-DSR as compared to the recommended NPK application in LCC managed $\mathrm{N}$.

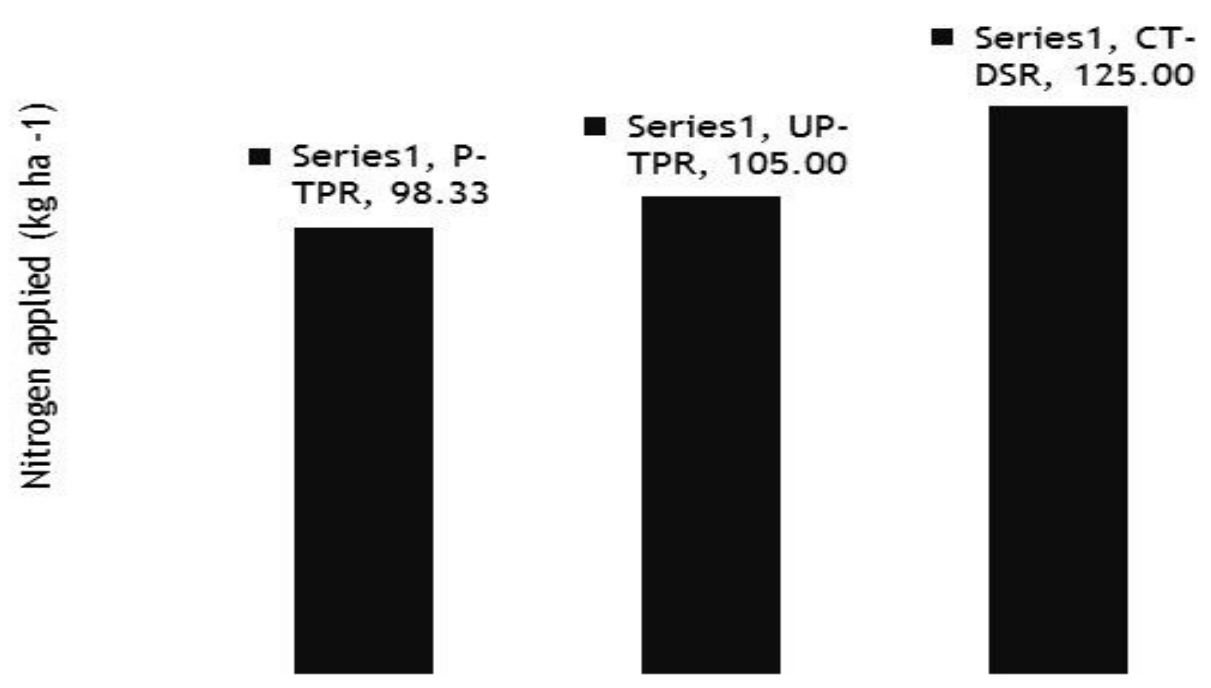

Establishment practices

Figure 1: Amount of nitrogen applied in LCC based nitrogen management as influenced by establishment methods and crop growth stages of rice at Rampur, Chitwan, Nepal, 2014 


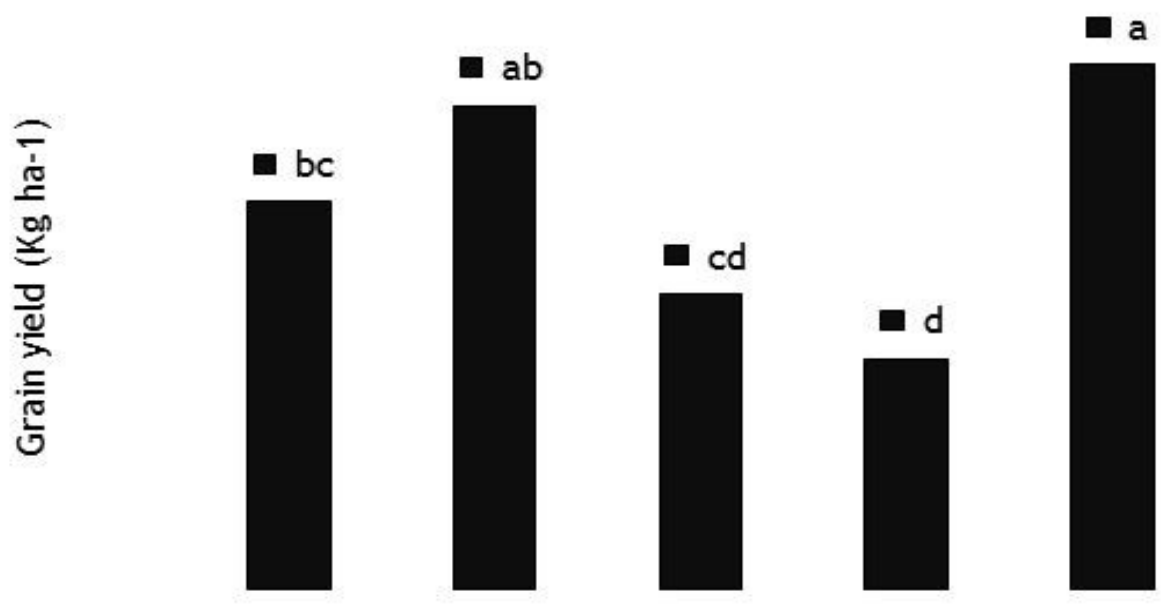

Nutrient management practices

Figure 2: Grain yield (Kg ha-1) of rice as influenced by nutrient management practices at Rampur, Chitwan, Nepal, 2014

\begin{tabular}{lccc}
\hline \multicolumn{1}{c}{ Treatments $\quad \begin{array}{c}\text { Number of effective tillers per square } \\
\text { meter }\end{array}$} & $\begin{array}{c}\text { Number of grains } \\
\text { per panicle }\end{array}$ & $\begin{array}{c}\text { Thousand grain } \\
\text { weight }(\mathbf{g})\end{array}$ \\
Establishment methods & $196.69^{\mathrm{a}}$ & 77 & 23.26 \\
\hline CT-DSR & $163.46^{\mathrm{b}}$ & 82.11 & 23.54 \\
UP-TPR & $171.13^{\mathrm{b}}$ & 86.93 & 23.12 \\
P-TPR & & & \\
Nutrient management & $185.20^{\mathrm{ab}}$ & $82.68^{\mathrm{ab}}$ & $23.51^{\mathrm{ab}}$ \\
\hline Rec. NPK & $186.18^{\mathrm{ab}}$ & $91.29^{\mathrm{a}}$ & $24.00^{\mathrm{a}}$ \\
LCC-N + Rec.PK & $171.71^{\mathrm{b}}$ & $80.44^{\mathrm{a}}$ & $22.66^{\mathrm{b}}$ \\
Farmers' practice & $142.16^{\mathrm{c}}$ & $68.49^{\circ}$ & $22.43^{\mathrm{b}}$ \\
0-N + Rec.PK & $200.22^{\mathrm{a}}$ & $87.17^{\mathrm{a}}$ & $23.94^{\mathrm{a}}$ \\
\hline 150 \% Rec. NPK & & & \\
\hline
\end{tabular}

Table 1: Effect of establishment and nutrient management practice in yield attributes of rice at Rampur, Chitwan, Nepal, 2014

The interaction effect of establishment methods and nutrient management practices were not significant but the slight changes in yield under different establishment methods in different nutrient management practices were observed. 

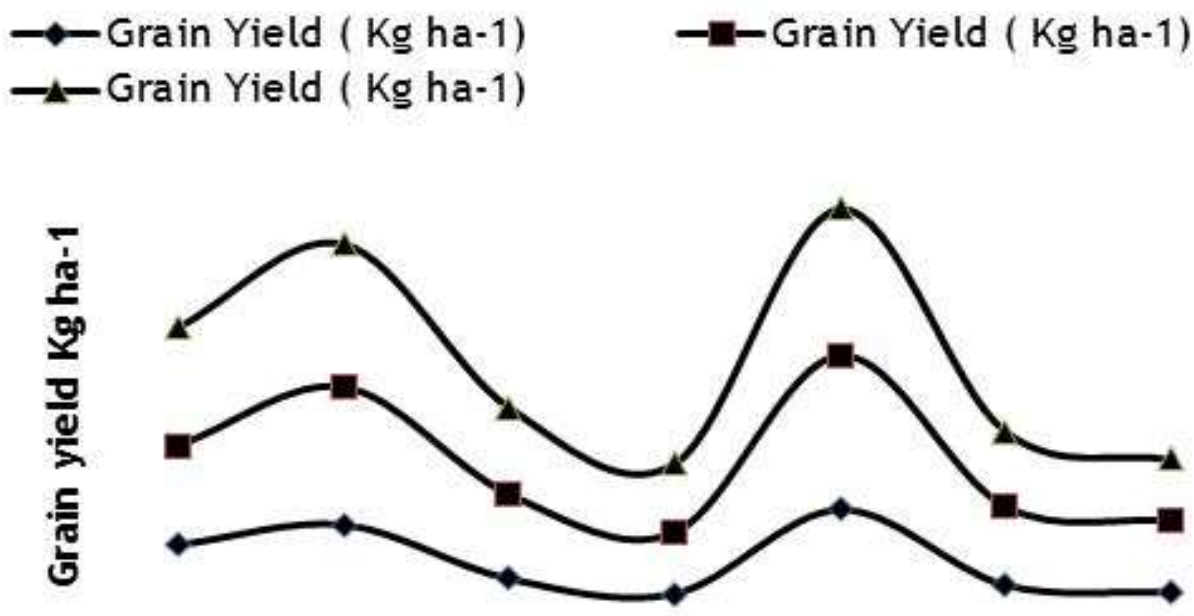

Nutrient management practices

Figure No.3: Interaction between establishment practice and nutrient management practice for grain yield of rice as influenced by the rice establishment methods and nutrient management practices at Rampur, Chitwan, Nepal during 2014

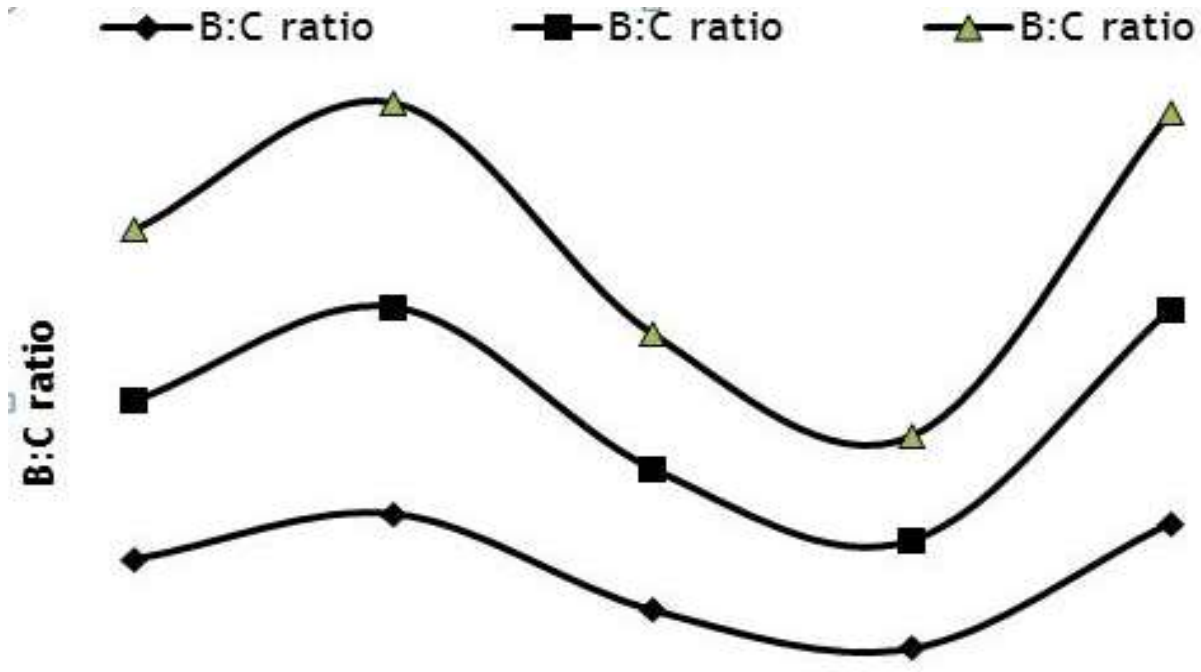

Nutreint management practices

Figure No.4: Interaction between establishment practice and nutrient management practice for $B: C$ ratio of rice as influenced by the rice establishment methods and nutrient management practices at Rampur, Chitwan, Nepal during 2014 


\section{DISCUSSION}

CT-DSR had higher effective tillers compared to P-TPR by $14.94 \%$ as seeds were sown continuously in the rows in CT-DSR which increases the number of plants per unit areas resulted in more number of main culm. In aerobic condition the effective tillers in the main culm is important than secondary tiller (Fageria, 2014) recommending higher seed rate and resulting higher effective tillers. Gathala et al. (2011) recorded more number of effective tillers per square meter under DSR compared with TPR.

Number of grains per panicle was higher in P-TPR than CT-DSR but all these are statistically similar. Similar type of finding was reported by Sah et al. (2007). Leaf dry weight and stem dry weight at 105 DAS was significantly associated $\left(r=0.620^{* *}\right.$ and $\left.r=724^{* *}\right)$ with the number of grains per panicle. As leaf dry weight and stem dry weight both were higher under P-TPR as compared to CTDSR resulted in higher number of grains per panicle under P-TPR. Thousand grain weight and sterility percentage both were also similar among the establishment methods but comparatively higher under CT-DSR as compared to P-TPR. Direct seeded rice produced higher number of sterile spike (Gathala et al., 2011), lower grain per panicle and lower thousands grain weight (Gathala et al., 2011) as compared to puddled TPR.

Grain yield was higher in CT-DSR compared to P-TPR and UP-TPR but not significant .Higher number of effective tillers per square meter $\left(r=0.66^{* *}\right)$ and slightly higher weight of unit grain $\left(r=0.64^{* *}\right)$ was main reason behind the higher grain yield. Straw yield was also higher for CT-DSR than UP-TPR and P-TPR. Thus the above ground biomass at harvest was also higher for CT-DSR compared to other practices. But the harvest index (ratio of $b$ iological yield to straw yield) was lower than both the practices as straw yield was higher compared to the grain yield than both the practices. Several researchers reported DSR systems can produce similar grain yield to TPR (Mabbbayad \& Buencosa, 1967). Some reports claim similar or even higher yields of DSR with good management practices (Ho \& Romli, 1998).

Cultivation cost for CT-DSR was drastically reduced and significantly beneficial as compared to UPTPR and P-TPR. The B:C ratio was significantly higher than other two practices. B:C ratio was $45 \%$ higher than traditional method of rice establishment i.e. P-TPR. Sah et al. (2007) reported that DSR was $51 \%$ higher in net return than P-TPR. The land preparation and transplantation cost is high in the conventional method of rice establishment due to higher labor requirement and the increasing wage rate in Asian countries. With the CT-DSR saving of $23 \%$ labor could be achieved according to Rehman et al. (2008). In Philippines even the labor saving could be carried out of about $40 \%$ as reported by Pandey and Velasco (1998).

Nitrogen requirement for LCC based N application under CT-DSR and UP-TPR were $27.12 \%$ and $6.78 \%$ higher as compared to P-TPR(Figure 1). Nitrogen loss through denitrification, volatilization, runoff and leaching is higher in aerobic condition than in anaerobic puddle condition (Davidson, 1991). Kumar \&Ladha(2011) reported higher mineralization in aerobic soil and subsequent loss was a main cause for higher requirement of N under UP-TPR and CT-DSR as compared to P-TPR. The longer crop growth duration in the main field under CT-DSR might be a cause for high need for nutrient requirement under DSR (Kumar \& Ladha, 2011) also reported the higher nitrogen requirement under dry tillage as in CT-DSR and UP-TPR than under P-TPR.

The Nitrogen requirement in LCC based $\mathrm{N}$ management was $109.44 \mathrm{Kg}$ ha compared to recommended level. In the present experiment, rice yield was responsive till $150 \%$ of recommended $\mathrm{N}$ but at par with LCC based $\mathrm{N}$ management with the saving of $41.56 \mathrm{Kg} \mathrm{N}$ ha ${ }^{-1}$. The LCC based $\mathrm{N}$ requirement was higher under CT-DSR followed by UP-TPR and least under P-TPR. The 
LCC based $\mathrm{N}$ management under P-TPR was slightly lower $(1.67 \%)$ as compared to recommended N. Marahatta (2008) also reported the lower amount of $\mathrm{N}$ requirement by $7.67 \mathrm{Kg}$ ha 1 through LCC

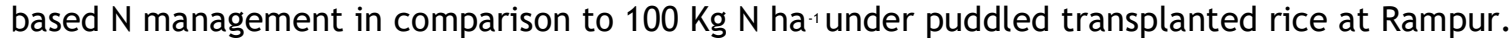

The effective tillers per square meter were higher for $150 \%$ of recommended NPK than any other nutrient management practices (Table 1). It was higher by 7.5 and $8 \%$ in this practice as compared to LCC based $\mathrm{N}$ management and recommended NPK (Table 1). According to (Fageria, 2014) tiller per square meter shows the quadratic equation and shows increasing trend up to $150 \mathrm{Kg} \mathrm{N} \mathrm{ha}{ }^{-1}$. LCC based $\mathrm{N}$ management was observed to be higher in number of grains per panicle, panicle length and thousand grain weight. Number of grains per panicle was highest for LCC based N management by $8.6 \%$ and $4.12 \%$ as compared to recommended NPK and $150 \%$ of recommended NPK respectively. Thousand grains weight was higher by $0.06 \mathrm{~g}$ and $0.49 \mathrm{~g}$ than $150 \%$ of recommended NPK and recommended NPK respectively as compared to LCC based N management. Sterility was higher in $150 \%$ recommended NPK. Ota and Yamada (1965) also reported that higher dose of Nitrogen induced sterility.

Marahattha (2008) reported higher number of grains per panicle than other nutrient management practices. Due to synchronized $\mathrm{N}$ application with crop demand, the recovery efficiency is high in LCC based $\mathrm{N}$ management. The recovery efficiency of top dressed urea during panicle initiation stage could be as high as 78\% (Peng \& Cassman, 1998). According to Kumara(1956), number of grains per panicle is directly related with $\mathrm{N}$ content in leaf blades at 1-4 week before flowering (known commonly as panicle fertilizer in Japan) and according to Wada and Matsushima (1962) effective tillers are related with $\mathrm{N}$ adsorbed at 17-18 days before flowering. Nitrogen was applied at every 10 days interval till flowering in LCC managed N; thus the plants' requirement was fulfilled increasing Grain per panicle and effective tillers in the experiment conducted. Top dressing at the time of spikelet differentiation leads to higher accumulation on carbohydrate at the time of heading and maturity (Sato, 1956). Thus LCC based $\mathrm{N}$ management till flowering is again beneficial here increasing growth of rice. Panicle fertilizer also contributes to the size of the yield container according to Murata (1969).

The grain and straw yield both were higher for $150 \%$ of recommended NPK. LCC managed + Rec. PK followed the former nutrient managed practice for both. Application of $150 \%$ of recommended NPK and LCC based N management yielded 35.19 and $24.76 \%$ higher grain yield compared with recommended NPK. As already explained, GPP, Thousand grain weight and Effective tillers have positive correlation with yield leading to higher yield in $150 \%$ of recommended NPK and sufficient and real time need application of $\mathrm{N}$

LCC based N management and 150\% of recommended NPK were both economically beneficial . Both of these practices were profitable by $76.81 \%$ and $88.67 \%$ compared with 3 split application of recommended N. B:C ratio was the highest for LCC based N application. It was higher by $22.38 \%$ and $1.74 \%$ than recommended NPK and $150 \%$ of recommended NPK. Maiti et al. (2004) also favors the use of LCC for management of rice as it is beneficial.

\section{CONCLUSION}

Direct seeding of rice under conventional tilled soil was better in terms of yield and economics as compared to transplanting in both puddled and unpuddled field. Unpuddled transplanting was also comparable to puddled transplanting. LCC based $\mathrm{N}$ showed the best performance in yield and economics under different nutrient management practices and comparable yield obtained along with saving of nitrogen to be applied. LCC based N application under direct seeded and transplanted rice produced higher yield and benefit enhancing the resource use efficiency under sub humid condition of Chitwan. 


\section{REFERENCES}

Al-Kaisi, M. \& Licht, M.A. (2004).Effect of strip on corn nitrogen uptake and residual soil nitrate accumulation compared with no-tillage and chisel plow. Agronomy Journal, 9,1164-1171.

Balasubramanian, V., Ladha, J. K., Gupta, R. K. , Naresh, R. K., Mehala, R. S., Singh, B. \& Singh, Y. (2003). Technology option for rice in rice wheat system in south Asia. In: J. K. Ladha, (Eds.), Improving the productivity and sustainability of rice wheat system: Issue and Impact. Los Banos, Philippines: International rice research institute.

Bodman, G.B., and Rubin J., 1968. Soil puddling. Soil Science Society of America Proc., 13,27-36.

Davidson, E. A. (1991). Fluxes of nitrous oxide and nitric oxide from terrestrial ecosystems. In J. E. Rogers and W. B. Whitman. (Eds), Microbial Production And Consumption Of Greenhouse Gases: Methane, Nitrogen Oxides and Halomethane. Washington, the American Society of Microbiology.

De Datta, S. K. \& R. J. Buresh.(1989). Integrated nitrogen management in irrigated rice.Advances of Soil Science, 10, 143-169.

De Datta, S. K. (1981). Principles and practices of rice production. Philippines, International Rice Research Institute.

De Datta, S. K. (1986). Improving fertilizer efficiency in lowland rice in tropical.Asia. Fertilizer Research, 9 , 171-186.

Fageria, N. K., Slaton, N. A., \& Baligar, V. C. (2003). Nutrient management for improving lowland rice productivity and sustainability. Advances in Agronomy, 80, 63-152.

Fageria, N.K., 1992. Maximizing crop yields. New York, Marcel Dekker.

FAO. (2014). A regional rice strategy for sustainable food security in asia and the pacific. Bangkok, Thailand: Food and Agriculture Organization of the United Nations.

Farooq, M., Basra, S.M.A \& Ahmad, N. (2007). Improving the performance of transplanted rice by seed priming. Plant Growth Regul., 51, 129-137.

George, T., Ladha, J. K., Buresh, R. J., \& Garrity, D. P. (1992).Managing native and legume-fixed nitrogen in lowland rice-based cropping systems. In Biological Nitrogen Fixation for Sustainable Agriculture (pp. 69-91). Netherlands, Springer.

Ghildyal, B. P. (1978). Effect of compaction and puddling on soil physical properties and rice growth. Soils and rice, 317-336.

Gopal, R., Jat, R.K., Malik, R.K., Kumar, V., Alam, M.M., Jat, M.L., Mazid, M.A., Sahrawat, Y.S., Mc Donald, A. \& Gupta, R. (2010). Direct dry seeded rice production technology and weed management in rice based systems. Technical bulletin.International Maize and Wheat Improvement Center.

Haefele, S.M. \& Hijmans, R.J.( 2007). Soil quality in rice-based rainfed lowlands of Asia: characterization and distribution. In: Aggarwal, P.K., Ladha, J.K., Singh, R.K., Devakumar, C., Hardy, B. (Eds.), Science, Technology, and trade for Peace and Prosperity. Proceedings of the 26th International Rice Research Conference, October 9-12, 2006, New Delhi, India.International Rice Research Institute/Indian Council of Agricultural Research, and National Academy of Agricultural Sciences, Los Ban os, Philippines.

Hussain, T., G.. Jilani \& Ghaffar A. (1989). Influence of rate and Time of N application on growth and yield of rice in Pakistan. International Rice research notes, 14(6), 18.

IRRI. (2014). World rice statistics online query facility. Retrieved April 23, 2015, from http://ricestat.irri.org:8080/wrs2/entrypoint.htm.

IRRI. (2015a). Increasing food security. Retrieved August 14, 2015, from http://irri.org/our-impact/increasefood-security.

IRRI.(2015b). Rice as a crop.Retrieved April 23, 2015, from http://ricepedia.org/.

Kumar, V., \& Ladha, J. K. (2011). Direct Seeding of Rice: recent developments and future research needs. Advances in Agronomy, 111, 297-413.

Kumura, A. (1956). Studies in the effect of internal nitrogen concentration of rice plant on the constitutional factor of yield. Proc. Crop Science society Japan, 24,324-330.

Ladha, J.K. \& Reddy, P.M. (2003). Nitrogen fixation in rice systems: state of knowledge and future prospect. Plant Soil, 252, 151-167. 
Ladha, J.K., Pathak, H., Krupnik, T.J., Six, J. \& Kessel, C.V.( 2005). Efficiency of fertilizer Nitrogen in cereal production: retrospect and prospects. Advances in Agronomy, 87, 86-158.

Mabbayad, B. B. \& Buencosa, I. A. (1967). Tests on minimal tillage of transplanted rice. Philipp Agric., 51,541-551.

Manzoor, Z., Awan, T. H., Zahid, M. A., \& Faiz, F. A. (2006). Response of rice crop (super basmati) to different nitrogen levels. Journal of Animal \& Plant Sciences, 16(1-2), 52-55.

Marahatta, S. (2008). Response of client oriented bred varieties under different nutrient management practices and their adoption pattern in western Chitwan of Nepal (Master Thesis, Tribhuwan University, Chitwan, Nepal).

Mikkelsen, D. S., De Datta, S. K., \& Obcemea, W. N. (1978).Ammonia volatilization losses from flooded rice soils. Soil Science Society of America Journal, 42(5), 725-730.

MoAD.(2012/13). Statistical information on Nepalese agriculture. Kathmandu, GON: Agri-statistics division.

August 5, 2014, from http://digitalcommons.unl.edu/agronomyfacpub.

NARC. (2007). Research highlights: 2002/03-2006/07 (pp. 17). Lalitpur, Nepal: Nepal Agricultural Research Council (NARC).

Ota, Y. \& Yamada, N. (1965).Studies on sterility of indica rice.Japan J. Trop. Agr., 9,76-79.

Pandey, S., \& Velasco, L. (2002). Economics of direct seeding in Asia: patterns of adoption and research priorities. In S. Pandey, M. Mortimer, L. Wade, T.P .Tuong, K. Lopez \& B. Hardy (Eds.), Direct seeding: research strategies and opportunities (pp. 3-14).Los Banos, Philippines: International Rice Research Institute.

Patil, S. K., Singh, U., Singh, V. P., Mishra, V. N., Das, R. O., \& Henao, J. (2001). Nitrogen dynamics and crop growth on an Alfisol and a Vertisol under a direct-seeded rainfed lowland rice-based system. Field Crops Research, 70(3), 185-199.

Rahaman M.H., Ali M.H., Ali M.M. \& Khatun M.M. (2007). Effect of different level of nitrogen on growth and yield of transplant Aman Rice CV BRRI dhan32. International Journal of Sustainainable Crop Production, 2(1), 28-34.

Reddy, K. R., Patrick, W. H., \& Broadbent, F. E. (1984).Nitrogen transformations and loss in flooded soils and sediments. Critical Reviews in Environmental Science and Technology, 13(4), 273-309.

Roy, R.N. \& Chandra, S. (1979). Increasing the efficiency of fertilizer use in India.Fertilizer industry, 17-27.

Russell, E. J., \& Richards, E. H. (1917). The changes taking place during the storage of farmyard manure. The Journal of Agricultural Science, 8(4), 495-563.

Sah, G. , Bhurer, K.P. , Upadhyay, I.P. , Ansar, N. , Chaudhary, D., Karna, P.L. , Adhikari, S.K. , Erenstein, O. \& Justice, S. (2007, June). On-farm Performance Evaluation of Aerobic Rice Technologies and Its Impact.National Summer Crops Workshop.

Salam, N. A., Tajuddin, E., Varghese, K., Hameed, S. M. S., \& Thomas, Y. (1988).Effect of N source and application time on rice.International Rice Research Newsletter, Philippines.

Sato, K. (1956). Studies in the starch content on the tissue of rice plant. . Proc. Crop Science society Japan, 24, 154-155.

Shimpi, S. S., \& Savant, N. K. (1975).Ammonia retention in tropical soils as influenced by moisture content and continuous submergence. Soil Science Society of America Journal, 39(1), 153-154.

Singh, S., Sharma, S. N., \& Prasad, R. (2001). The effect of seeding and tillage methods on productivity of ricewheat cropping system. Soil and Tillage Research, 61(3), 125-131.

Sloan, J. J., \& Anderson, W. B. (1995). Calcium chloride and ammonium thiosulfate as ammonia volatilization inhibitors for urea fertilizers. Communications in Soil Science \& Plant Analysis, 26(15-16), 2425-2447.

Vlek, P. L., \& Byrnes, B. H. (1986). 7. The efficacy and loss of fertilizer $N$ in lowland rice. Fertilizer Research, 9(1-2), 131-147.

Wada, G. \& Matshushima, S. (1962). Analysis of yield-determining process and its application to yield prediction and culture improvement of lowland rice.Proc. Crop Science society Japan, 31, 23-26.

Williams, W. A., Mikkelsen, D. S., Mueller, K. E., \& Ruckman, J. E. ( 1968). Nitrogen immobilization by rice straw incorporated in lowland rice production. Plant Soil, 28, 49. 